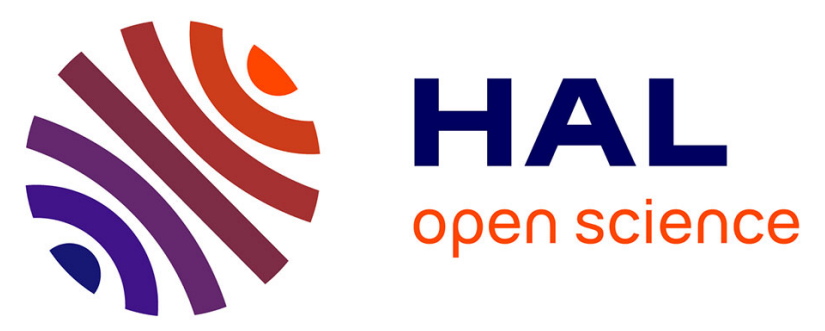

\title{
Selective 1H-1H Distance Restraints in Fully Protonated Proteins by Very Fast Magic-Angle Spinning Solid-State NMR
}

\author{
Mukul G Jain, Daniela Lalli, Stanek Jan, Chandrakala Gowda, Satya
}

Prakash, Tom S Schwarzer, Tobias Schubeis, Kathrin Castiglione, Loren B

Andreas, P. K. Madhu, et al.

\section{To cite this version:}

Mukul G Jain, Daniela Lalli, Stanek Jan, Chandrakala Gowda, Satya Prakash, et al.. Selective $1 \mathrm{H}-1 \mathrm{H}$ Distance Restraints in Fully Protonated Proteins by Very Fast Magic-Angle Spinning Solid-State NMR. Journal of Physical Chemistry Letters, 2017, 8 (11), pp.2399-2405. 10.1021/acs.jpclett.7b00983 . hal-01544734

\author{
HAL Id: hal-01544734 \\ https://hal.science/hal-01544734
}

Submitted on 15 Mar 2018

HAL is a multi-disciplinary open access archive for the deposit and dissemination of scientific research documents, whether they are published or not. The documents may come from teaching and research institutions in France or abroad, or from public or private research centers.
L'archive ouverte pluridisciplinaire HAL, est destinée au dépôt et à la diffusion de documents scientifiques de niveau recherche, publiés ou non, émanant des établissements d'enseignement et de recherche français ou étrangers, des laboratoires publics ou privés. 


\section{Selective ${ }^{1} \mathrm{H}-{ }^{1} \mathrm{H}$ Distance Restraints in Fully}

\section{Protonated Proteins by Very Fast Magic-Angle}

\section{Spinning Solid-State NMR}

Mukul G Jain,,$^{a, t}$ Daniela Lalli, ${ }^{,+}$Jan Stanek, ${ }^{b}$ Chandrakala Gowda, ${ }^{a}$ Satya Prakash, ${ }^{a}$ Tom S.

Schwarzer, ${ }^{c}$ Tobias Schubeis, ${ }^{b}$ Kathrin Castiglione, ${ }^{c}$ Loren B. Andreas, ${ }^{d}$ P.K. Madhu, ${ }^{a, e}$ Guido

Pintacuda $^{b}$ and Vipin Agarwal ${ }^{*}$

${ }^{a}$ TIFR Centre for Interdisciplinary Sciences, Tata Institute of Fundamental Research, 21

Brundavan Colony, Narsingi, Hyderabad 500 075, India

${ }^{\text {b}}$ Centre de RMN à Très Hauts Champs, Institut des Sciences Analytiques (UMR 5280 - CNRS,

ENS Lyon, UCB Lyon 1), Université de Lyon, 5 rue de la Doua, 69100 Villeurbanne, France

'Institute of Biochemical Engineering, Technical University of Munich, Boltzmannstraße 15, D85748 Garching, Germany

${ }^{\mathrm{d}}$ Max Planck Institute for Biophysical Chemistry, Am Fassberg 11, D-37077 Göttingen,

Germany

e Department of Chemical Sciences, Tata Institute of Fundamental Research, Homi Bhabha Road, Colaba, Mumbai 400 005, India 
ABSTRACT: Very fast magic-angle spinning (MAS>80 kHz) NMR combined with high field magnets has enabled the acquisition of proton-detected spectra in fully protonated solid samples with sufficient resolution and sensitivity. One of the primary challenges in structure determination of protein is to observe long-range ${ }^{1} \mathrm{H}-{ }^{1} \mathrm{H}$ contacts. Here we use band-selective spin-lock pulses to obtain selective ${ }^{1} \mathrm{H}-{ }^{1} \mathrm{H}$ contacts $\left(\right.$ e.g. $\left.\mathrm{H}^{\mathrm{N}}-\mathrm{H}^{\mathrm{N}}\right)$ on the order of 5-6 $\AA$ in fully protonated proteins at $111 \mathrm{kHz}$ MAS. This approach is a major advancement in structural characterization of proteins given that magnetization can be selectively transferred between protons that are 5-6 $\AA$ apart despite the presence of other protons at shorter distance. The observed contacts are similar to those previously observed only in perdeuterated proteins with selective protonation. Simulations and experiments show the proposed method has superior performance compared to the currently used methods. The method is demonstrated on GB1 and a $\beta$-barrel membrane protein, AlkL.

\section{TOC GRAPHICS}

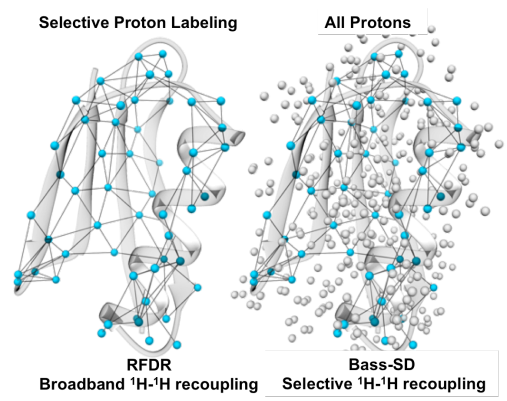


Solid-state nuclear magnetic resonance (NMR) spectroscopy with magic-angle spinning (MAS) has emerged as a powerful technique for characterizing the structure and dynamics of complex biomolecules that are particularly challenging to other spectroscopic techniques such as X-ray or cryo-electron microscopy. A growing panel of such structural investigations is now reported using solid-state NMR spectroscopy, ranging from amyloid fibrils, membrane proteins, bone matrix and capsids (to cite only a few recent examples) ${ }^{1-6}$ Conventionally, this technique exploits the detection of carbon signals, which offer high site-specific resolution. However, the direct detection of proton signals is eight-fold more sensitive. Until recently, the acquisition of resolved proton-detected spectra of proteins was feasible only when the network of strong proton-proton homonuclear dipolar couplings is weakened by replacement of a substantial fraction of the proton nuclei with deuterons. ${ }^{7-12}$ At MAS frequency above $45 \mathrm{kHz}$, it is possible to use deuterated samples with $100 \%$ protonation of exchangeable sites for structural characterization. $^{10,13-15}$

The availability of small diameter rotors has enabled faster spinning, decreased the protein sample quantity to few nanomoles ${ }^{16}$ and most importantly yields resolved proton spectra of fully protonated samples. ${ }^{617-19}$ Recently, we showed that at MAS frequencies of $100 \mathrm{kHz}$ and above, narrow proton lines enabled unambiguous assignment of resonances in fully protonated proteins and subsequent de novo structure determination..$^{19,20}$

Typically, backbone dihedral-angle restraints combined with short and long distance restraints are required to initiate a structure calculation. While backbone dihedral angles are easily accessible via backbone chemical shifts, obtaining long-range distance restraints in fully protonated solids at fast MAS still remains a challenge. However, significant progress has been 
made to characterize small molecules and bones structure using proton-only multidimensional experiments. $^{21}$ First-order recoupling sequences, such as radio frequency driven recoupling (RFDR) of ${ }^{1} \mathrm{H}$ nuclei, are effective in providing distance restraints in perdeuterated and selectively reprotonated proteins. ${ }^{9,10,22}$ Recently, ${ }^{1} \mathrm{H}$ recoupling using MIRROR was also proposed to enhance spin diffusion in such samples. ${ }^{23}$ At slow MAS, distance restraints in fullyprotonated systems have been obtained through second-order recoupling sequences such as DARR/MIRROR, ${ }^{24-26}$ and PAR/PAIN. ${ }^{27-29}$ The efficiency of the latter methods, however, decreases with increasing MAS frequency. As a result at $111 \mathrm{kHz}$ MAS, RFDR was used to obtain ${ }^{1} \mathrm{H}-{ }^{1} \mathrm{H}$ distance restraints in fully protonated proteins. ${ }^{20}$ At such fast MAS frequency, RFDR recoupling of protons leads to rapid decay of signal, requires high RF amplitude pulses ( $>200 \mathrm{kHz})$ and provides a limited set of long-range ${ }^{1} \mathrm{H}-{ }^{1} \mathrm{H}$ contacts.

Here, we introduce a new experimental method to observe selective proton-proton contacts in fully protonated proteins at fast MAS frequencies by using low-amplitude spin-lock pulses. The experiment, referred to as "Band-Selective Spectral Spin Diffusion" (BASS-SD), can be used to selectively detect $\mathrm{H}^{\mathrm{N}}-\mathrm{H}^{\mathrm{N}}, \mathrm{H}^{\alpha}-\mathrm{H}^{\alpha}$ or $\mathrm{H}^{\text {methyl }}-\mathrm{H}^{\text {methyl }}$ proximities up to a distance of $5-6 \AA$ despite the presence of other protons at shorter distances in fully protonated proteins. The observed correlations are analogous to those observed in perdeuterated proteins with partial protonation. ${ }^{16,22}$ This is experimentally demonstrated on two uniformly ${ }^{13} \mathrm{C},{ }^{15} \mathrm{~N}$-labelled protein samples: a model protein and a membrane protein.

For spinning samples, the rate of spin diffusion $\left(k_{12}\right.$, Eq.1) between two spins depends on the Fourier components of the dipolar coupling $\left(\omega_{i j}^{( \pm n)}\right)$, the MAS frequency $\left(\omega_{r}\right)$ and indirectly (through the zero-quantum (ZQ) lineshape) on the isotropic chemical-shift difference $\left(\Delta \omega_{\text {iso }}\right)$ between the two spins..$^{30,31}$ 


$$
k_{12}=\sum_{n=-2}^{+2} \omega_{i j}^{(+n)} \omega_{i j}^{(-n)} J\left(n \omega_{r}+\Delta \omega_{i s o}\right) \text { Eq. } 1
$$

Spin diffusion occurs when the difference in chemical shift is smaller than the ZQ dipolar line width. ${ }^{31}$ Spin-diffusion can be made band selective if the chemical-shift difference between the spins in one part of the spectrum is reduced to be smaller than the ZQ line width while, at the same time, ensuring that the chemical-shift difference to the other spins, resonating outside the selected region, is actively maintained. This condition can be achieved in the rotating frame by employing highly offset-dependent spin-lock pulses. During the spin-lock period, the chemicalshift difference between the protons located in a particular spectral region (e.g. amide protons) can be minimized by carefully adjusting the RF amplitude while the other protons (e.g aliphatic) are in a tilted frame (defined by amplitude of spin-lock pulse and chemical-shift offset). This results in polarization exchange exclusively between protons located within the bandwidth of the spin-lock pulse. (e.g. amide protons).

The polarization exchange during the BASS-SD scheme was numerically simulated as a function of different parameters using GAMMA. ${ }^{32}$ Figure 1a) shows the topology of an eightspin system used for simulation of polarization buildup on seven spins when only one of the spin is initially polarized $\left(2 \mathrm{H}^{\mathrm{N}}\right)$. The spin system comprises four aliphatic and four amide protons $\left(\mathrm{H}^{\mathrm{N}}\right)$ where the amide/aliphatic proton distinction is made based on the chemical shifts. The isotropic chemical shifts and distances of the seven protons relative to the source spin $\left(2 \mathrm{H}^{\mathrm{N}}\right)$ are provided in Figure 1 and are representative of spin-systems typically encountered in protein samples. The spin-lock offset was set to $8 \mathrm{ppm}$ (center of the amide proton chemical shift range) and the effect of proton relaxation was neglected. All other simulation parameters are reported in supporting information (SI). The simulated 2D plots (Figure $\mathbf{1 b}-\mathbf{h}$ ), as a function of the spin-lock RF field and duration indicate that for spin-lock RF field of 5-10 kHz, the amide-amide proton 
polarization transfer is more efficient in comparison to the amide-aliphatic proton transfer, despite the generally longer distances amongst the amide protons. This is a consequence of the difference in scaled chemical shifts being larger than the ZQ line widths in the rotating frame. A comparison of the two geminal $\mathrm{H}^{\alpha}$ plots (Figure 1f, g) shows that despite the stronger dipolar couplings for $4 \mathrm{H}^{\alpha}$, the polarization transfer efficiency decreases with increasing chemical-shift offset between the source and destination spins. Even when the distances between the amide protons were artificially doubled while the distances between the source amide proton and the aliphatic proton were kept the same, polarization transfer exclusively occurs only within the amide protons (Figure S1). 

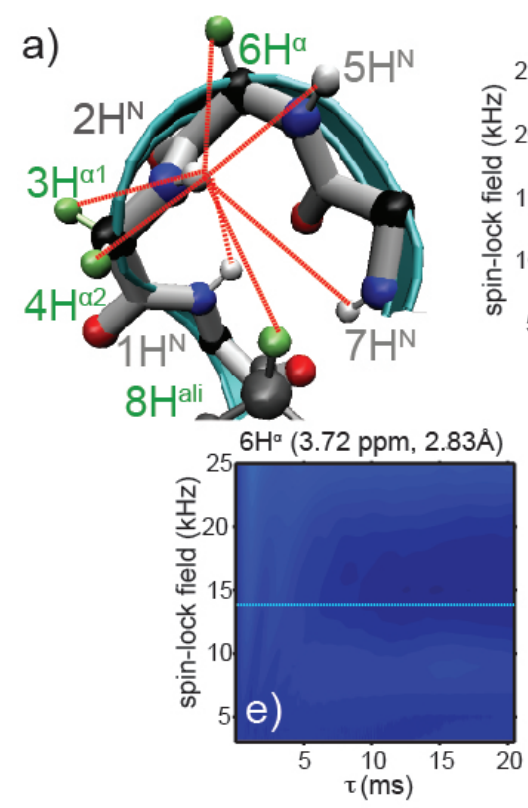

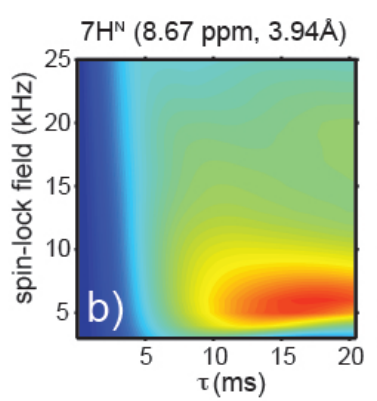

$3 \mathrm{H}^{\alpha 1}(4.13 \mathrm{ppm}, 2.88 \AA)$

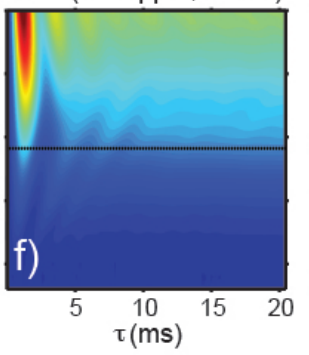

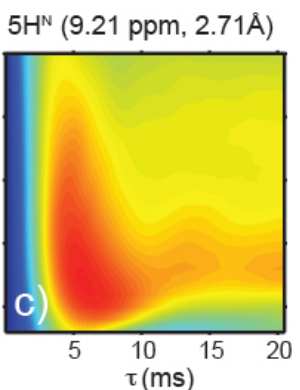

$4 \mathrm{H}^{02}(3.47 \mathrm{ppm}, 2.26 \AA)$

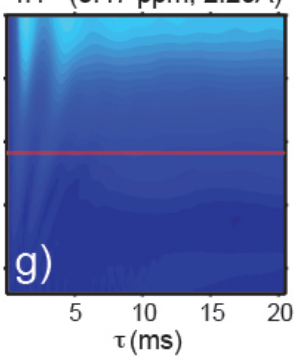

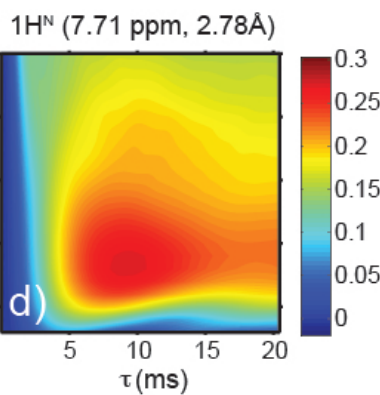

$8 \mathrm{H}^{\mathrm{ali}}(0.73 \mathrm{ppm}, 3.30 \AA)$

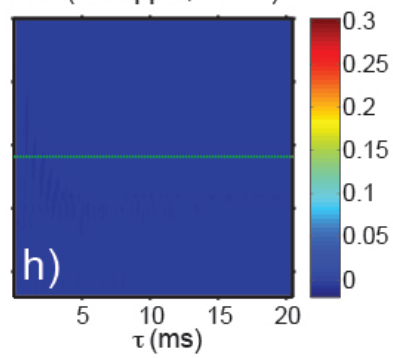

Figure 1. a) Simulated spin system: the source spin $\left(2 \mathrm{H}^{\mathrm{N}}\right)$, the three closest amide protons (white spheres) and the four closest aliphatic protons (green spheres). b-h) Polarization build up as a function of spin-lock field strength and time for different spins: amide protons: $7 \mathrm{H}^{\mathrm{N}}$ b), $5 \mathrm{H}^{\mathrm{N}}$ c), $1 \mathrm{H}^{\mathrm{N}} \mathrm{d}$ ), the aliphatic spin: $\alpha$-proton $6 \mathrm{H}^{\alpha}$ e), geminal $\alpha$-protons $3 \mathrm{H}^{\alpha 1}$ f) $4 \mathrm{H}^{\alpha 2}$ g) and $8 \mathrm{H}^{\text {ali }} \mathrm{h}$ )

The efficiency of BASS-SD was experimentally verified on a microcrystalline sample of fullyprotonated immunoglobulin beta 1 binding domain of protein $\mathrm{G}(\mathrm{GB} 1) \cdot{ }^{33}$ The BASS-SD mixing was incorporated into the 3D $(\mathrm{H}) \mathrm{NHH}($ Figure 2a) and the better resolved 3D $(\mathrm{H}) \mathrm{N}(\mathrm{H})(\mathrm{H}) \mathrm{NH}$ experiments. ${ }^{10,15}$ Overlay of $2 \mathrm{D}(\mathrm{H}) \mathrm{NH}$ and the $2 \mathrm{D}(\mathrm{H}) \mathrm{N}(\mathrm{H}) \mathrm{H}-\mathrm{BASS}-\mathrm{SD}$ spectra (Figure 2b) shows polarization transfer occurs exclusively amongst the amide protons and negligible magnetization flows from the amide protons to other aliphatic protons. 

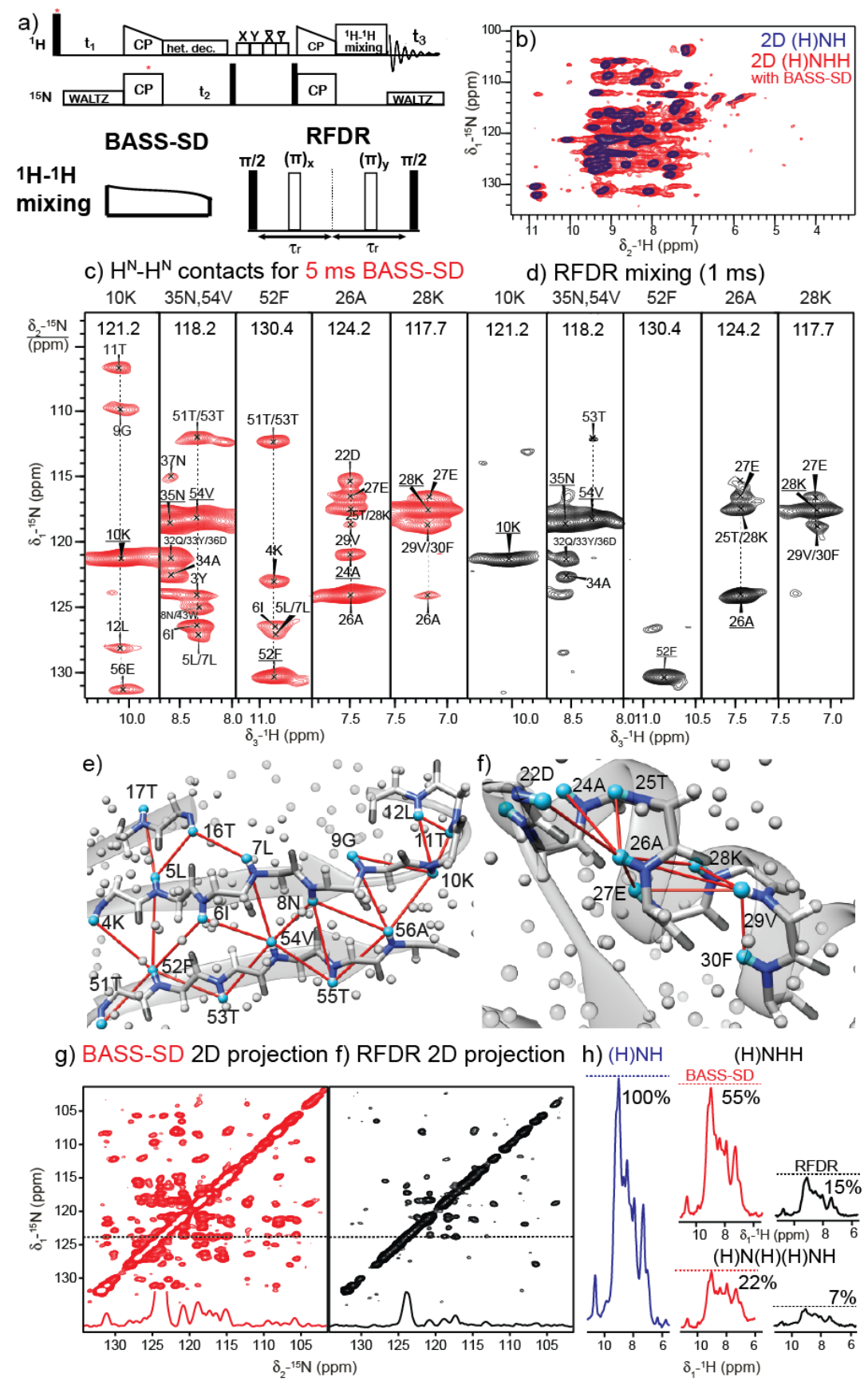

Figure 2 a) pulse sequence for the 3D (H)NHH experiment b) Overlay of 2D (H)NH (Blue) and 2D $(\mathrm{H}) \mathrm{N}(\mathrm{H}) \mathrm{H}-\mathrm{BASS}-\mathrm{SD}\left(\right.$ Red) spectra. c-d) $\mathrm{H}^{\mathrm{N}}-\mathrm{H}^{\mathrm{N}}$ restraints from 3D $(\mathrm{H}) \mathrm{N}(\mathrm{H})(\mathrm{H}) \mathrm{NH}$ spectra of fully protonated $\mathrm{U}-\left[{ }^{13} \mathrm{C},{ }^{15} \mathrm{~N}\right]-\mathrm{GB} 1$ at $111.11 \mathrm{kHz}$ MAS with c) BASS-SD (red, $5 \mathrm{~ms}$ ) and d) RFDR ( black, $1 \mathrm{~ms}$ ) mixing. Observed $\mathrm{H}^{\mathrm{N}}-\mathrm{H}^{\mathrm{N}}$ correlations across the e) $\beta$-sheet and $\mathrm{f}$ ) $\alpha$-helix motifs are mapped on the X-ray structure of GB1 (PDB code: 2QMT ${ }^{34}$ ). Cyan and grey spheres 
denote amide and other protons, respectively, while the dark gray and blues sticks represent the backbone atoms. $2 \mathrm{D}{ }^{15} \mathrm{~N}-{ }^{15} \mathrm{~N}$ positive projections from the 3D spectra are shown in $\mathrm{g}$ ) for BASSSD and h) RFDR, i) ${ }^{15} \mathrm{~N}$ - filtered $1 \mathrm{D}$ proton intensity comparison after RFDR and BASS-SD mixing for different experiments.

Figure 2c) depicts $2 \mathrm{D}{ }^{1} \mathrm{H}-{ }^{15} \mathrm{~N}$ strips extracted from a 3D $(\mathrm{H}) \mathrm{N}(\mathrm{H})(\mathrm{H}) \mathrm{NH}$ BASS-SD spectrum ( ${ }^{1} \mathrm{H}$ RF amplitude $\sim 5.5 \mathrm{kHz}$ ). The observed $\mathrm{H}^{\mathrm{N}}-\mathrm{H}^{\mathrm{N}}$ correlations for residues located in the $\beta$ sheets $(10 \mathrm{~K}, 52 \mathrm{~F}$ and $54 \mathrm{~V})$ and $\alpha$-helix $(26 \mathrm{~A}, 28 \mathrm{~K}$ and $35 \mathrm{~N})$ are mapped on to the X-ray structure (Figure 2e-f). The $\mathrm{H}^{\mathrm{N}}$ of $52 \mathrm{~F}, 54 \mathrm{~V}$ and $56 \mathrm{E}$ residues on the $\beta 4$ strand show unambiguous correlations to amide protons of residues in the $\beta 1$ strand. The amide protons of $26 \mathrm{~A}$ and $28 \mathrm{~K}$ show correlations to other amide protons only within the $\alpha$-helix. It is well known that lack of helix-sheet amide restraints creates problems in the orientation of the $\alpha$-helix relative to the $\beta$-strands. ${ }^{10,16}$ Therefore, in most cases structure determination requires additional sidechain restraints. We used BASS mixing to observe selective $\mathrm{H}^{\alpha}-\mathrm{H}^{\alpha}$ or $\mathrm{H}^{\text {methyl }}-\mathrm{H}^{\text {methyl }}$ contacts in GB1 by fine-tuning the carrier offset frequency and the ${ }^{1} \mathrm{H}$ RF amplitude to suit their welldefined chemical shift ranges (Figure 3).

In contrast to BASS-SD proton mixing, a similar 3D spectrum acquired with $1 \mathrm{~ms}$ of RFDR mixing (Figure 2d, ${ }^{1} \mathrm{H}$ RF amplitude $\sim 200 \mathrm{kHz}$ ) shows correlations only within the $\alpha$-helix. The $2 \mathrm{D}{ }^{15} \mathrm{~N}-{ }^{15} \mathrm{~N}$ projection from the 3D $(\mathrm{H}) \mathrm{N}(\mathrm{H})(\mathrm{H}) \mathrm{NH}$ spectra (Figure 2 g-h) shows significantly more number of peaks with BASS-SD mixing in comparison to RFDR. Figure 2i) shows that the envelope of the detected proton signal is approximately 3-4 times higher with BASS-SD in comparison to RFDR mixing. The higher sensitivity of the BASS-SD mixing compensates for the loss in sensitivity imposed by two additional cross-polarization steps required to record the better resolved 3D $(\mathrm{H}) \mathrm{N}(\mathrm{H})(\mathrm{H}) \mathrm{NH}$ experiment. Even for well behaved samples such as GB1, the 
observed proton linewidth (0.1-0.3 ppm) at $111 \mathrm{kHz}$ MAS are at the limit of proton resolution that can be used to unambiguously assign 3D restrain spectra with two proton dimensions. ${ }^{20}$ Therefore, distance restraint spectra involving two heteronuclear dimensions will be absolutely necessary for obtaining unambiguous contacts in fully protonated proteins. The lower sensitivity of RFDR results from the fact that the majority of polarization is transferred to (unobserved) aliphatic and aromatic protons.

a) Methyl-methyl contacts for 5 ms Bass-SD vs 1 ms RFDR
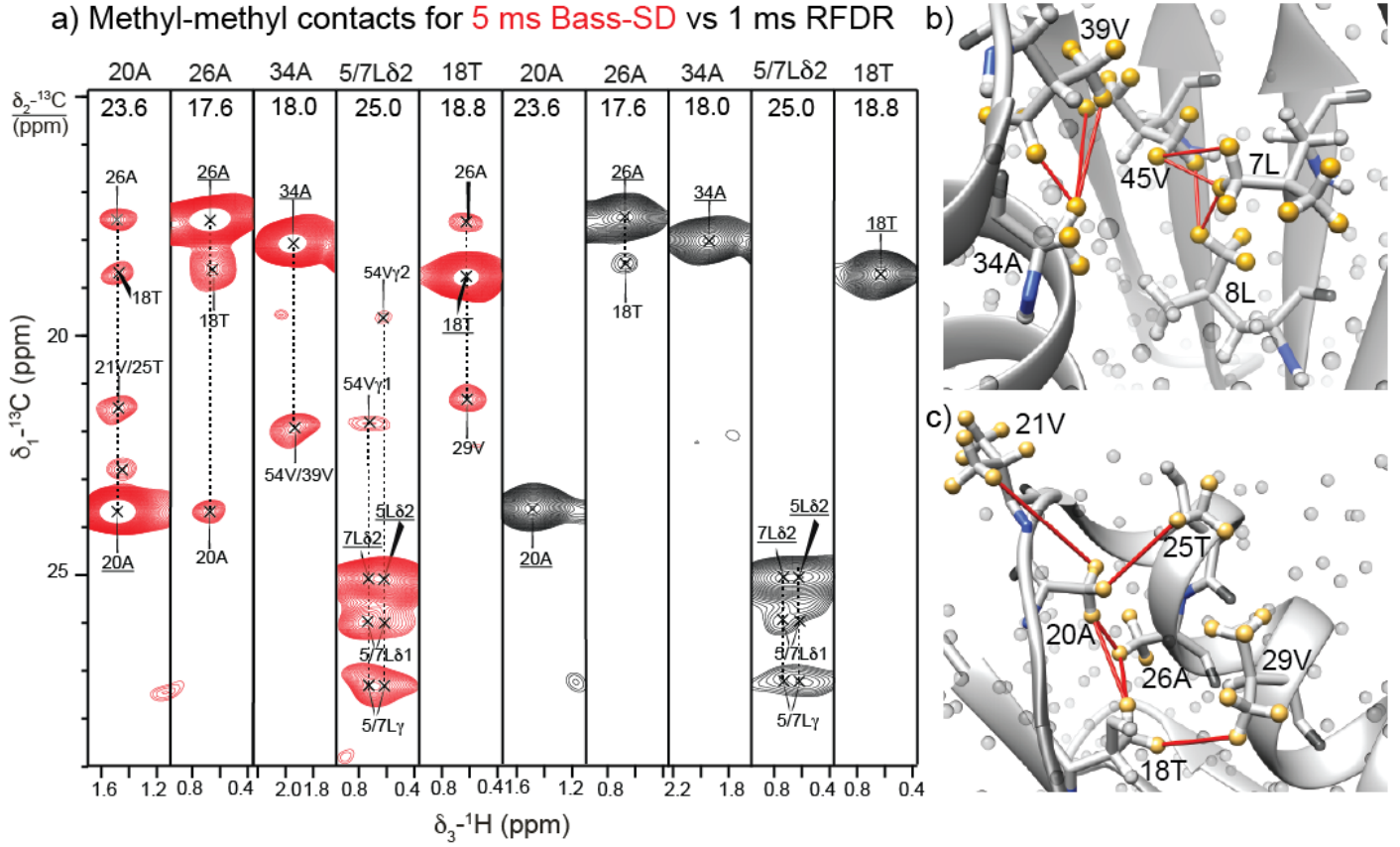

c) $2021 \mathrm{~V}$

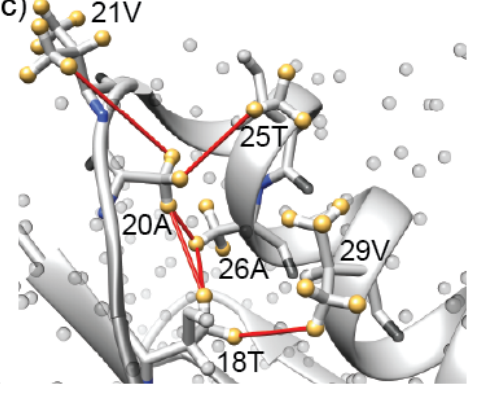

d)

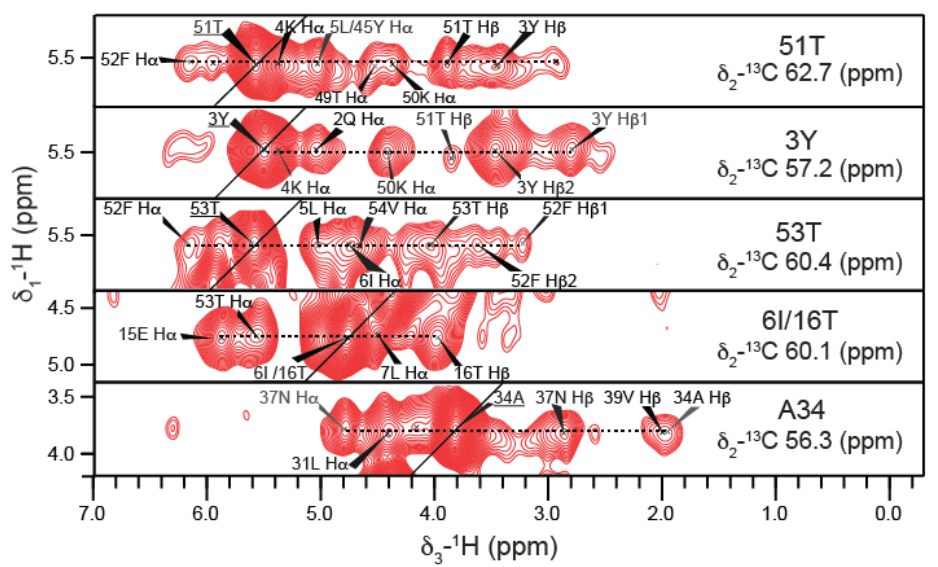

e)

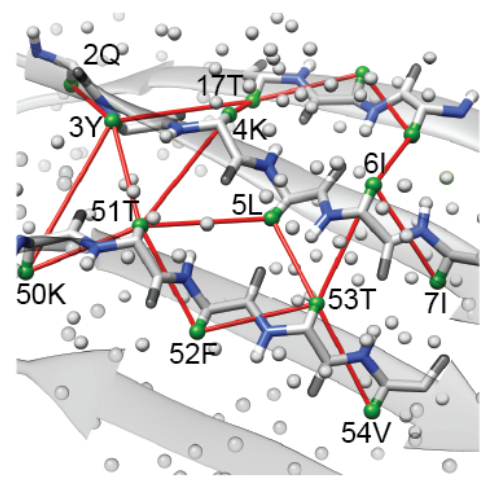


Figure 3 a) Cross-sections from a 3D $(\mathrm{H}) \mathrm{C}(\mathrm{H})(\mathrm{H}) \mathrm{CH}$ spectrum with $5 \mathrm{~ms}$ of BASS-SD (in red) and $1 \mathrm{~ms}$ of RFDR (in black) mixing show the methyl-methyl contacts in $\mathrm{U}-\left[{ }^{13} \mathrm{C},{ }^{15} \mathrm{~N}\right]-\mathrm{GB} 1 . \mathrm{b}, \mathrm{c}$ ) Correlations observed in the BASS-SD cross-sections in (a) are reported on the X-ray structure of GB1 (PDB code: 2QMT). The yellow spheres represent the methyl protons. All other protons are shown as grey spheres. d) $\mathrm{H}^{\alpha}-\mathrm{H}^{\alpha}$ contacts observed from a 3D (H)CHH spectrum. e) The green spheres represent the $\alpha$ protons while all other protons are shown as grey spheres.

The chemical shift overlap of methyl and alpha protons with other aliphatic protons makes the implementation of the BASS-SD mixing scheme for $\mathrm{H}^{\alpha}$ or methyl protons more challenging. The ${ }^{1} \mathrm{H}$ RF-amplitude and the offset of the spin lock pulse were fine tuned to ensure polarization exchange only between protons located within $\sim 0-2 \mathrm{ppm}$ for the methyl and $\sim 3-6$ ppm for the alpha protons (Table S2). The offset was chosen corresponding to the center of the chemical shifts range of the protons to be recoupled. The ${ }^{1} \mathrm{H}$ RF amplitude and the duration of the spinlock pulse were optimized experimentally through a series of ${ }^{15} \mathrm{~N} /{ }^{13} \mathrm{C}$ edited two-dimensional $(\mathrm{H}) \mathrm{N}(\mathrm{H}) \mathrm{H} /(\mathrm{H}) \mathrm{C}(\mathrm{H}) \mathrm{H}$ spectra (measurement time was 5-10 minutes per spectrum) to have maximum cross-peaks. Figure 3a) shows $2 \mathrm{D}{ }^{1} \mathrm{H}-{ }^{13} \mathrm{C}$ cross-sections (red contours) extracted from a 3D $(\mathrm{H}) \mathrm{C}(\mathrm{H})(\mathrm{H}) \mathrm{CH}-\mathrm{BASS}-\mathrm{SD}$ spectrum for the methyl groups. Several long-range methylmethyl correlations are observed and are depicted on the X-ray structure (Figure 3b-c). Such methyl-methyl distance restraints are critical in determining the correct fold of a protein, and have previously been observed only with perdeuterated proteins having selectively labeled methyl groups. ${ }^{16,35}$ In contrast, RFDR mixing again yields fewer contacts in comparison to BASS-SD (black strips in Figure 3a). The residues with two methyl groups such as valine, 
leucine and isoleucine result in the strongest contact between the pro- $S$ and pro- $R$ methyl groups (e.g. L5 and L7 in Figure 3a). A 3D (H)NHH-BASS-SD experiment was recorded to observe selective $\mathrm{H}^{\alpha}-\mathrm{H}^{\alpha}$ contacts. The two-proton dimensions increase the ambiguity in peak assignments. Therefore, previously, reported proton chemical shifts in combination with X-ray structure were used to assign the observed correlation in Figure 3d. The observed correlations are mapped on to the X-ray structure (Figure 3e) and provide complementary restraints to those obtained from the $\mathrm{H}^{\mathrm{N}}-\mathrm{H}^{\mathrm{N}}$ experiment.

a)
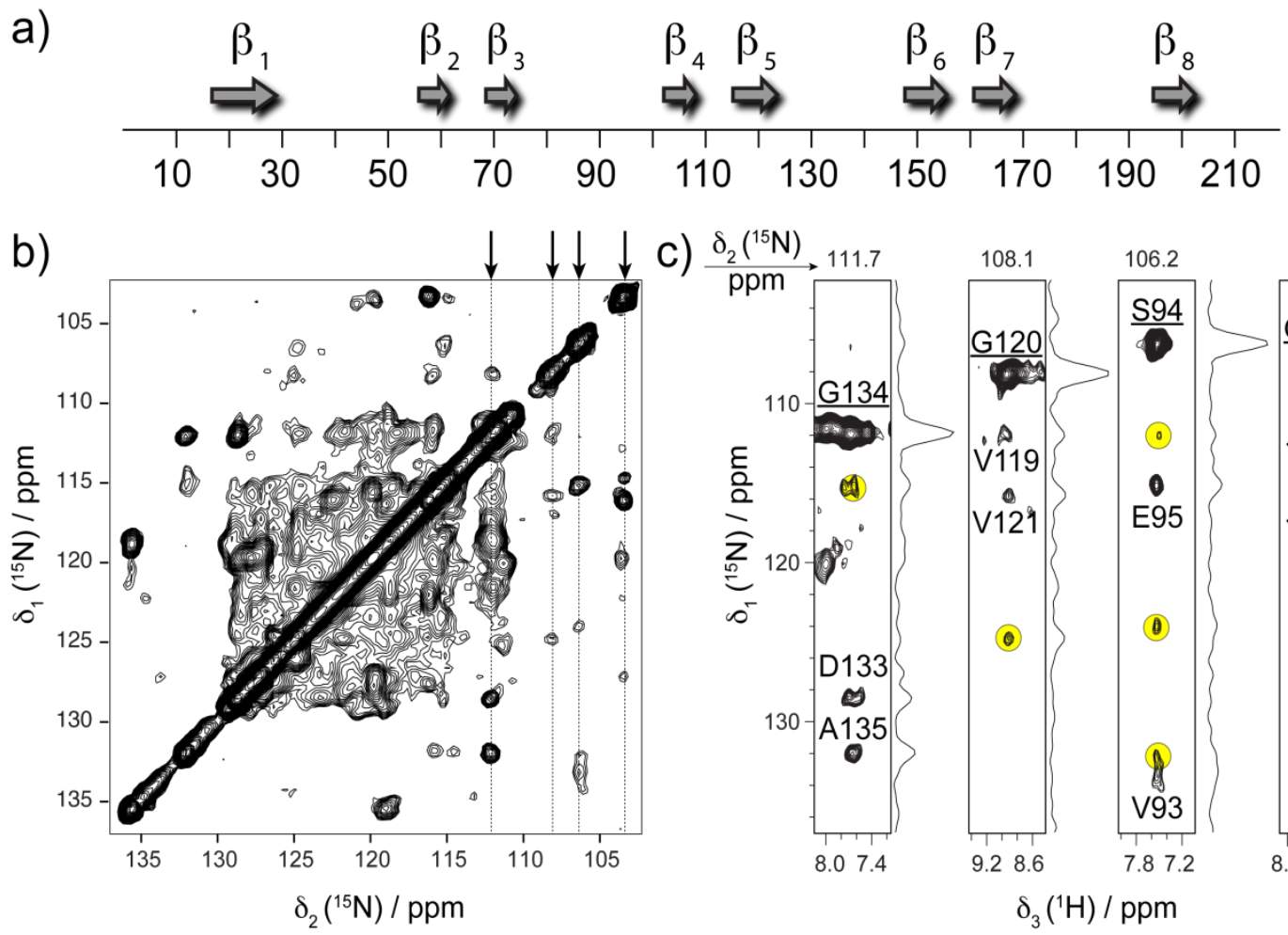

C) $\underset{p p m}{\frac{\delta_{2}\left({ }^{15} \mathrm{~N}\right)}{p m}} 111.7$
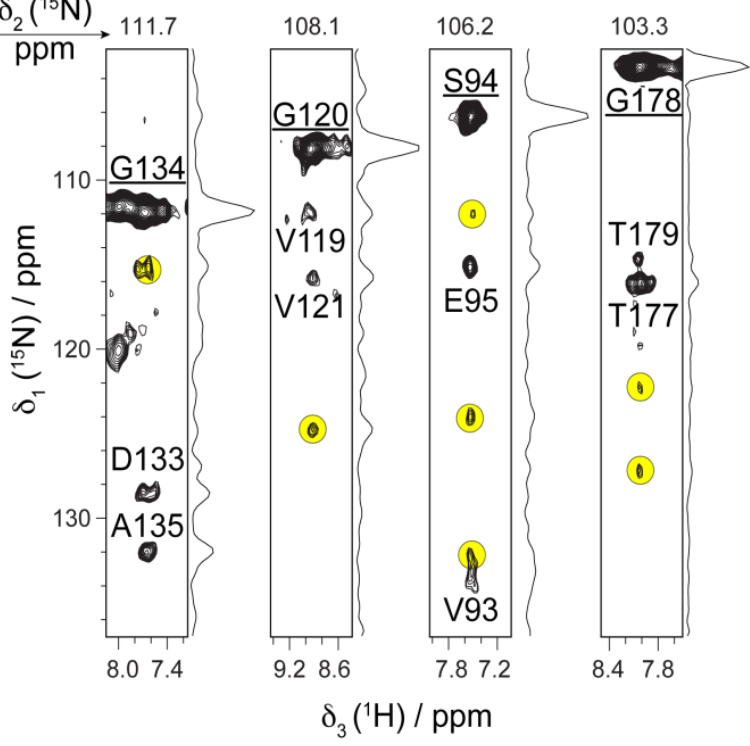
Figure $4 \mathrm{H}^{\mathrm{N}}-\mathrm{H}^{\mathrm{N}}$ contacts from $3 \mathrm{D}(\mathrm{H}) \mathrm{N}(\mathrm{H})(\mathrm{H}) \mathrm{NH}$-BASS-SD spectrum of $\mathrm{U}-\left[{ }^{13} \mathrm{C},{ }^{15} \mathrm{~N}\right]-\mathrm{AlkL}$ protein recorded at MAS frequency of $111.11 \mathrm{kHz}$ and on a $1000 \mathrm{MHz}$ spectrometer. a) Sequence homology prediction of secondary structure of AlkL b) $2 \mathrm{D}{ }^{15} \mathrm{~N}-{ }^{15} \mathrm{~N}$ projection of the $3 \mathrm{D}$ spectrum shows high density of cross-peaks. c) $\omega_{1}\left({ }^{15} \mathrm{~N}\right)-\omega_{3}\left(\mathrm{H}^{\mathrm{N}}\right)$ strips from 3D contain a number of additional correlations (highlighted in yellow) in addition to identified sequential peaks. The underlined labels denote auto-correlation signals.

The broad applicability of BASS-SD ${ }^{1} \mathrm{H}-{ }^{1} \mathrm{H}$ mixing is also demonstrated on a sample of the outer membrane protein AlkL from Pseudomonas putida (218 residues) embedded in lipid bilayers. ${ }^{36}$ AlkL is involved in transport of hydrophobic molecules and comprises eight TM $\beta$-strands as predicted by sequence homology (Figure 4a). U- $\left[{ }^{13} \mathrm{C},{ }^{15} \mathrm{~N}\right]$ - AlkL sample is challenging for solidstate NMR due to less effective packing of the protein in the rotor, lower sample homogeneity and shorter coherence lifetimes. Figure $4 \mathbf{b}$ shows the $2 \mathrm{D}{ }^{15} \mathrm{~N}-{ }^{15} \mathrm{~N}$ projection obtained from the 3D $(\mathrm{H}) \mathrm{N}(\mathrm{H})(\mathrm{H}) \mathrm{NH}-\mathrm{BASS}-\mathrm{SD}$ spectrum. Representative strips (Figure 4c) extracted from the 3D spectrum show a number of distinct correlations, besides the ones expected from sequential $\mathrm{H}^{\mathrm{N}}-\mathrm{H}^{\mathrm{N}}$ contacts. The detailed interpretation of cross-peaks is currently impeded by the incomplete assignment; however, we anticipate the $\mathrm{H}^{\mathrm{N}}-\mathrm{H}^{\mathrm{N}}$ distance restrains to be crucial for determination of relative orientation of $\beta$-strands and thus the overall $\beta$-barrel fold of the protein. Also in the case of AlkL, the observed sensitivity of experiments with BASS-SD mixing was higher than RFDR (Figure S3), thus fully corroborating the results obtained for microcrystalline GB1. 
To conclude, we have proposed a new methodology to access selective long-range $\mathrm{H}^{\mathrm{N}}-\mathrm{H}^{\mathrm{N}}, \mathrm{H}^{\alpha}-$ $\mathrm{H}^{\alpha}$ and $\mathrm{H}^{\text {methyl }}-\mathrm{H}^{\text {methyl }}$ contacts in fully-protonated solid proteins with high sensitivity. The selective correlations observed with the BASS-SD scheme are analogous to those previously accessible only in perdeuterated proteins with protonation at selective sites. BASS-SD is different from the presently used approach of recoupling the entire proton bath with broadband recoupling sequences (e.g. RFDR). Compared to RFDR, BASS-SD has better performance in terms of sensitivity, density of cross peaks and has lower RF requirement, making it particularly suitable for protein structure determination. BASS-SD has allowed us to obtain restraints in the membrane protein AlkL, which were otherwise not possible with RFDR. With increase in static magnetic field the proton resolution and the selectivity of the BASS-SD scheme would only become better. We envisage this method to be widely used in structure determination of fully protonated proteins at fast-MAS. The small sample volume and use of fully protonated protein should widen the range of biomolecules that can be studied by solid-state NMR spectroscopy. We will explicitly discuss the theoretical foundation of spin dynamics during BASS-SD mixing in the near future.

\section{ASSOCIATED CONTENT}

Supporting Information. Numerical simulations of the BASS-SD with doubled distances; sample preparation details and the NMR experimental parameters are included. The Supporting Information is available free of charge on the ACS Publications.

\section{AUTHOR INFORMATION}

Corresponding Author:

Email: vipina@tifrh.res.in 
Notes: \$These authors (MJ and DL) contributed equally.

The authors declare no competing financial interests.

\section{ACKNOWLEDGMENT:}

We acknowledge Prof Matthias Ernst, ETH, Zurich, for useful discussions, Dr Rajalakshmi and

Dr Kaustubh Mote for proof reading the manuscript. We declare no competing financial interests. We acknowledge financial support from CNRS (IR-RMN FR3050, TGIR-RMN00874) and from the European Research Council (ERC) under the European Union's Horizon 2020 research and innovation programme (ERC-2015-CoG GA n648974). JS is supported by a MC incoming fellowship (REA grant agreement n661799 “COMPLEX-FAST- MAS”). TS and KC would like to acknowledge the funding German Federal Ministry of Education and Research (BMBF grant number 031A178).

\section{REFERENCES}

(1) Xiao, Y.; Ma, B.; McElheny, D.; Parthasarathy, S.; Long, F.; Hoshi, M.; Nussinov, R.; Ishii, Y. A $\beta(1-42)$ Fibril Structure Illuminates Self-Recognition and Replication of Amyloid in Alzheimer's Disease. Nat. Struct. Mol. Biol. 2015, 22 (6), 499-505.

(2) Colvin, M. T.; Silvers, R.; Ni, Q. Z.; Can, T. V.; Sergeyev, I.; Rosay, M.; Donovan, K. J.; Michael, B.; Wall, J.; Linse, S.; et al. Atomic Resolution Structure of Monomorphic A 342 Amyloid Fibrils. J. Am. Chem. Soc. 2016, 138 (30), 9663-9674.

(3) Wälti, M. A.; Ravotti, F.; Arai, H.; Glabe, C. G.; Wall, J. S.; Böckmann, A.; Güntert, P.; Meier, B. H.; Riek, R. Atomic-Resolution Structure of a Disease-Relevant A $\beta(1-42)$ Amyloid Fibril. Proc. Natl. Acad. Sci. U.S.A. 2016, 113 (34), E4976-E4984.

(4) Morag, O.; Abramov, G.; Goldbourt, A. Complete Chemical Shift Assignment of the ssDNA in the Filamentous Bacteriophage Fd Reports on Its Conformation and on Its Interface with the Capsid Shell. J. Am. Chem. Soc. 2014, 136 (6), 2292-2301.

(5) Andreas, L. B.; Reese, M.; Eddy, M. T.; Gelev, V.; Ni, Q. Z.; Miller, E. A.; Emsley, L.; Pintacuda, G.; Chou, J. J.; Griffin, R. G. Structure and Mechanism of the Influenza a M2 18-60Dimer of Dimers. J. Am. Chem. Soc. 2015, 137 (47), 14877-14886.

(6) Mroue, K. H.; Nishiyama, Y.; Kumar Pandey, M.; Gong, B.; McNerny, E.; Kohn, D. H.; 
Morris, M. D.; Ramamoorthy, A. Proton-Detected Solid-State NMR Spectroscopy of Bone with Ultrafast Magic Angle Spinning. Sci.Rep. 2015, 5, 11991.

Agarwal, V.; Diehl, A.; Skrynnikov, N.; Reif, B. High Resolution ${ }^{1} \mathrm{H}$ Detected ${ }^{1} \mathrm{H},{ }^{13} \mathrm{C}$ Correlation Spectra in MAS Solid-State NMR Using Deuterated Proteins with Selective ${ }^{1} \mathrm{H},{ }^{2} \mathrm{H}$ Isotopic Labeling of Methyl Groups. J. Am. Chem. Soc. 2006, 128 (39), 1262012621.

(8) Chevelkov, V.; Rehbein, K.; Diehl, A.; Reif, B. Ultrahigh Resolution in Proton SolidState NMR Spectroscopy at High Levels of Deuteration. Angew. Chem. Int. Ed. Engl. 2006, 45 (23), 3878-3881.

(9) Paulson, E. K.; Morcombe, C. R.; Gaponenko, V.; Dancheck, B.; Byrd, R. A.; Zilm, K. W. High-Sensitivity Observation of Dipolar Exchange and NOEs Between Exchangeable Protons in Proteins by 3D Solid-State NMR Spectroscopy. J. Am. Chem. Soc. 2003, 125 (47), 14222-14223.

(10) Zhou, D. H.; Shea, J. J.; Nieuwkoop, A. J.; Franks, W. T.; Wylie, B. J.; Mullen, C.; Sandoz, D.; Rienstra, C. M. Solid-State Protein-Structure Determination with ProtonDetected Triple-Resonance 3D Magic-Angle-Spinning NMR Spectroscopy. Angew. Chem. Int. Ed. Engl. 2007, 46 (44), 8380-8383.

(11) Ward, M. E.; Shi, L.; Lake, E.; Krishnamurthy, S.; Hutchins, H.; Brown, L. S.; Ladizhansky, V. Proton-Detected Solid-State NMR Reveals Intramembrane Polar Networks in a Seven-Helical Transmembrane Protein Proteorhodopsin. J. Am. Chem. Soc. 2011, 133 (43), 17434-17443.

(12) Barbet-Massin, E.; Pell, A. J.; Retel, J. S.; Andreas, L. B.; Jaudzems, K.; Franks, W. T.; Nieuwkoop, A. J.; Hiller, M.; Higman, V.; Guerry, P.; et al. Rapid Proton-Detected NMR Assignment for Proteins with Fast Magic Angle Spinning. J. Am. Chem. Soc. 2014, 136 (35), 12489-12497.

(13) Knight, M. J.; Webber, A. L.; Pell, A. J.; Guerry, P.; Barbet-Massin, E.; Bertini, I.; Felli, I. C.; Gonnelli, L.; Pierattelli, R.; Emsley, L.; et al. Fast Resonance Assignment and Fold Determination of Human Superoxide Dismutase by High-Resolution Proton-Detected Solid-State MAS NMR Spectroscopy. Angew. Chem. Int. Ed. 2011, 50 (49), 1169711701.

(14) Linser, R.; Bardiaux, B.; Andreas, L. B.; Hyberts, S. G.; Morris, V. K.; Pintacuda, G.; Sunde, M.; Kwan, A. H.; Wagner, G. Solid-State NMR Structure Determination From Diagonal-Compensated, Sparsely Nonuniform-Sampled 4D Proton-Proton Restraints. $J$. Am. Chem. Soc. 2014, 136 (31), 11002-11010.

(15) Huber, M.; Hiller, S.; Schanda, P.; Ernst, M.; Böckmann, A.; Verel, R.; Meier, B. H. A Proton-Detected 4D Solid-State NMR Experiment for Protein Structure Determination. ChemPhysChem 2011, 12 (5), 915-918.

(16) Agarwal, V.; Penzel, S.; Szekely, K.; Cadalbert, R.; Testori, E.; Oss, A.; Past, J.; Samoson, A.; Ernst, M.; Böckmann, A.; et al. De Novo 3D Structure Determination From Sub-Milligram Protein Samples by Solid-State $100 \mathrm{kHz}$ MAS NMR Spectroscopy. Angew. Chem. Int. Ed. Engl. 2014, 53 (45), 12253-12256.

(17) Lamley, J. M.; Iuga, D.; Öster, C.; Sass, H.-J.; Rogowski, M.; Oss, A.; Past, J.; Reinhold, A.; Grzesiek, S.; Samoson, A.; et al. Solid-State NMR of a Protein in a Precipitated Complex with a Full-Length Antibody. J. Am. Chem. Soc. 2014, 136 (48), 16800-16806.

(18) Zhang, R.; Nishiyama, Y.; Sun, P.; Ramamoorthy, A. Phase Cycling Schemes for Finite- 
Pulse-RFDR MAS Solid State NMR Experiments. J. Magn. Reson. 2015, 252, 55-66. Stanek, J.; Andreas, L. B.; Jaudzems, K.; Cala, D.; Lalli, D.; Bertarello, A.; Schubeis, T.; Akopjana, I.; Kotelovica, S.; Tars, K.; et al. NMR Spectroscopic Assignment of Backbone and Side-Chain Protons in Fully Protonated Proteins: Microcrystals, Sedimented Assemblies, and Amyloid Fibrils. Angew. Chem. Int. Ed. 2016, 55 (50), 15504-15509.

(20) Andreas, L. B.; Jaudzems, K.; Stanek, J.; Lalli, D.; Bertarello, A.; Le Marchand, T.; Cala-De Paepe, D.; Kotelovica, S.; Akopjana, I.; Knott, B.; et al. Structure of Fully Protonated Proteins by Proton-Detected Magic-Angle Spinning NMR. Proc. Natl. Acad. Sci. U.S.A. 2016, 201602248-18.

(21) Zhang, R.; Mroue, K. H.; Ramamoorthy, A. Proton-Based Ultrafast Magic Angle Spinning Solid-State NMR Spectroscopy. Acc. Chem. Res. 2017, 50 (4), 1105-1113.

(22) Linser, R.; Bardiaux, B.; Higman, V.; Fink, U.; Reif, B. Structure Calculation From Unambiguous Long-Range Amide and Methyl 1H- 1H Distance Restraints for a Microcrystalline Protein with MAS Solid-State NMR Spectroscopy. J. Am. Chem. Soc. 2011, 133 (15), 5905-5912.

(23) Wittmann, J. J.; Agarwal, V.; Hellwagner, J.; Lends, A.; Cadalbert, R.; Meier, B. H.; Ernst, M. Accelerating Proton Spin Diffusion in Perdeuterated Proteins at $100 \mathrm{kHz}$ MAS. J. Biomol. NMR 2016, 66 (4), 233-242.

(24) Takegoshi, K.; Nakamura, S.; Terao, T. ${ }^{13} \mathrm{C}-{ }^{1} \mathrm{H}$ Dipolar-Driven ${ }^{13} \mathrm{C}-{ }^{13} \mathrm{C}$ Recoupling Without ${ }^{13} \mathrm{C}$ Rf Irradiation in Nuclear Magnetic Resonance of Rotating Solids. J. Chem. Phys. 2003, 118 (5), 2325-18.

(25) Scholz, I.; Huber, M.; Manolikas, T.; Meier, B. H.; Ernst, M. MIRROR Recoupling and Its Application to Spin Diffusion Under Fast Magic-Angle Spinning. Chem. Phys. Lett. 2008, 460 (1-3), 278-283.

(26) Morcombe, C. R.; Gaponenko, V.; Byrd, R. A.; Zilm, K. W. Diluting Abundant Spins by Isotope Edited Radio Frequency Field Assisted Diffusion. J. Am. Chem. Soc. 2004, 126 (23), 7196-7197.

(27) De Paëpe, G.; Lewandowski, J. R.; Loquet, A.; Böckmann, A.; Griffin, R. G. Proton Assisted Recoupling and Protein Structure Determination. J. Chem. Phys. 2008, 129 (24), 245101-245121.

(28) Scholz, I.; Meier, B. H.; Ernst, M. NMR Polarization Transfer by Second-Order Resonant Recoupling: RESORT. Chem. Phys. Lett. 2010, 485 (4-6), 335-342.

(29) Agarwal, V.; Sardo, M.; Scholz, I.; Böckmann, A.; Ernst, M.; Meier, B. H. PAIN with and Without PAR: Variants for Third-Spin Assisted Heteronuclear Polarization Transfer. J. Biomol. NMR 2013, 56 (4), 365-377.

(30) Kubo, A.; Mcdowell, C. A. Spectral Spin Diffusion in Polycrystalline Solids Under Magic-Angle Spinning. J Chem Soc, Faraday Trans 1988, 84 (11), 3713-3730.

(31) Ernst, M.; Meier, B. H. Chapter 4 Spin Diffusion in Solids; Studies in Physical and Theoretical Chemistry; Elsevier, 1998; Vol. 84, pp 83-121.

(32) Smith, S. A.; Levante, T. O.; Meier, B. H.; Ernst, R. R. Computer Simulations in Magnetic Resonance. an Object-Oriented Programming Approach. J. Magn. Reson. A 1994, $106(1), 75-105$.

(33) Franks, W. T.; Zhou, D. H.; Wylie, B. J.; Money, B. G.; Graesser, D. T.; Frericks, H. L.; Sahota, G.; Rienstra, C. M. Magic-Angle Spinning Solid-State NMR Spectroscopy of the Beta1 Immunoglobulin Binding Domain of Protein G (GB1): ${ }^{15} \mathrm{~N}$ and ${ }^{13} \mathrm{C}$ Chemical 
Shift Assignments and Conformational Analysis. J. Am. Chem. Soc. 2005, 127 (35), 12291-12305.

(34) Schmidt, H. L. F.; Sperling, L. J.; Gao, Y. G.; Wylie, B. J.; Boettcher, J. M.; Wilson, S. R.; Rienstra, C. M. Crystal Polymorphism of Protein GB1 Examined by Solid-State NMR Spectroscopy and X-Ray Diffraction. J Phys Chem B 2007, 111 (51), 1436214369.

(35) Huber, M.; Hiller, S.; Schanda, P.; Ernst, M.; Böckmann, A.; Verel, R.; Meier, B. H. A Proton-Detected 4D Solid-State NMR Experiment for Protein Structure Determination. ChemPhysChem 2011, 12 (5), 915-918.

(36) Schwarzer, T. S.; Hermann, M.; Krishnan, S.; Simmel, F. C.; Castiglione, K. Preparative Refolding of Small Monomeric Outer Membrane Proteins. Protein Expr. Purif. 2017, $132,171-181$. 